\title{
DEVELOPMENT OF HYPERLINK-BASED AUDIO VISUAL MEDIA FOR SIX-GRADE SCIENCE LEARNING
}

\author{
Ummu Kulsum Syarifah ${ }^{1}$, Ahmad Noor Fatirul ${ }^{2}$, Harwanto $^{3}$ \\ Universitas PGRI Adi Buana Surabaya
}

\begin{abstract}
The ability of teachers as educators in creating a conducive and effective learning atmosphere as well as fun is the main goal in the learning process. The use of learning media through hyperlink-based audio visual in the learning process is the main choice in generating interest and motivation of students in learning activities. Audio visual media is a multimedia device that integrates various types of media such as the sound of an animated text, video image inserted into the created program. The use of this media is an interactive instructional media which will help the effectiveness of the learning process in delivering the content of the lesson. This study aimed to determine the effectiveness and interest in the use of learning media through hyperlink- based audio visual which was held at elementary school in Bangkalan subdistrict for 20 sixth-grade students learning the science subjects about the solar system in the form of Microsoft power point. This study was a research and development following the model suggested by Dick and Carey. This method was used to generate the product and can be used in education as reference of learning. The results of research indicate that the instructional media through hyperlink-based audio visual used in the activities learning has a high level of effectiveness and interest in students in the learning process activities, especially on science subjects seen from the motivation of students in asking and answering.
\end{abstract}

Keyword: Audio Visual,Development, Learning Media,Science

\begin{abstract}
Abstrak: Kemampuan guru sebagai pendidik dalam menciptakan suasana belajar yang kondusif dan efektif serta kesenangan yang merupakan tujuan utama dalam proses pembelajaran. Penggunaan media pembelajaran melalui audio visual berbasis hyperlink dalam proses pembelajaran merupakan pilihan utama dalam membangkitkan minat dan motivasi siswa dalam kegiatan pembelajaran. Media audio visual adalah perangkat multimedia yang mengintegrasikan berbagai jenis media seperti suara teks animasi, gambar video dimasukkan ke dalam program yang dibuat. Penggunaan media ini adalah media pembelajaran interaktif yang akan membantu efektivitas proses pembelajaran dalam menyampaikan konten pelajaran. Penelitian ini bertujuan untuk mengetahui efektivitas dan minat dalam penggunaan media pembelajaran melalui audio visual berbasis hyperlink yang diadakan di sekolah dasar di Bangkalan untuk 20 siswa kelas enam yang mempelajari mata pelajaran sains tentang tata surya dalam bentuk kekuatan Microsoft. titik. Penelitian ini adalah penelitian dan pengembangan mengikuti model yang disarankan oleh Dick dan Carey. Metode ini digunakan untuk menghasilkan produk dan dapat digunakan dalam pendidikan sebagai referensi pembelajaran. Hasil penelitian menunjukkan bahwa media pembelajaran melalui audio visual berbasis hyperlink yang digunakan dalam kegiatan pembelajaran memiliki tingkat efektivitas dan minat yang tinggi pada siswa dalam kegiatan proses pembelajaran, terutama pada mata pelajaran IPA dilihat dari motivasi siswa dalam bertanya dan menjawab.
\end{abstract}

Kata Kunci: Audio Visual, Pengembangan, Media Pembelajaraan, IPA

\footnotetext{
'Universitas PGRI Adi Buana, Email: ummu syarifah

${ }^{2}$ Universitas PGRI Adi Buana Surabaya, Email: anfatirul国gmail.com

${ }^{3}$ Universitas PGRI Adi Buana Surabaya, Email: harwanta
} 


\section{INTRODUCTION}

One of problems faced by Indonesian people is about education, especially primary and secondary school. Various efforts have been made by the government through the Ministry of National Education to improve the quality of national education, for example through various training and enhancement the resources of education personnel, improving curriculum, procurement of books, learning tools, school management, developing teaching materials, and developing new paradigms with teaching methodologies and enhancements quality of school education management, but the quality of education has not shown adequate improvement.

The most dominant cause of educational problems is the ability of teachers to improve their competence in the learning process. The use of methods and models must be more creative and innovative in utilizing and making instructional media. Teachers are required to be able to use the tools provided by the school in the form of the intensive coordination with themes (known as KIT) and information technology or abbreviated as IT.

Instructional media is one of important components in teaching and learning process. Media is a tool that helps and makes the teachers easy to provide lessons to students so that they can generate knowledge, comprehension, motivation and stimuli in every learning activity. The use of instructional media is closely related to the development of Science and Technology. The development of science and technology increasingly encourages renewal in the use of technology results in the learning process.

Instructional media is one of important components in teaching and learning process. Media is a tool that helps and makes the teachers easy to provide lessons to students so that they can generate knowledge, comprehension, motivation and stimuli in every learning activity. The use of instructional media is closely related to the development of Science and Technology. The development of science and technology increasingly encourages renewal in the use of technology results in the learning process.

Science is a very enjoyable lesson about the environment and surroundings, but many students think that science is very saturating and too much memorization. This is because students are lazy to read, supported by the teaching pattern of teachers who still apply lecturing method and expect students to sit, be quiet, listen, note and memorize. Based on the problems in the process of teaching and learning activities, the use of instructional media through hyperlinkbased audio visuals is an alternative in overcoming these problems. The development of instructional media through hyperlink-based audio visuals can improve students' abilities and understanding of the material to be delivered by the teacher. Hyperlink-based audio visual media is a medium that is related to the power point that has been modified so that it will make students more interesting and easy to obtain lessons. According to Dale (Arsyad, 2016) that audio visual materials can provide many benefits unless the teacher plays an active role in the process of learning activities.

The purpose of developing the instructional media through hyperlinkbased audiovisuals was to motivate the students in learning so that they did not get bored and drilled in learning so that students are in a joyful situation so that it can generate sportive competition of learning process in developing the students' skills to ask and answer questions 
and improve the results of the learning process optimally.

Therefore, the researchers developed an instructional media through hyperlink-based audio visual because the instructional media through hyperlinkbased audiovisuals had never been done and used in the learning process. This development was expected to increase the students' motivation and interest in learning.

The outstanding characteristics of instructional media development through hyperlink-based audio visuals, namely:

1. Hyperlink-based audio visual is one of the power point software in a computer that combines text, images and video integrated by links, encouraging students to be more interested in viewing learning videos.

2. Media development products through audio visual can be watched and learned together through a modified computer that impress students.

In the development of instructional media used in the learning process, there are limitations to the model, including:

1. It is only used in learning material with more sound images and interesting shows so that it will be more enjoyable in teaching and learning process.

2. The product development of instructional media through -based audio visuals is based on the characteristics and needs of students,

3. The use of instructional media through hyperlink-based audiovisual that use power points to make students interested in the learning process. Hyperlink-based audio visual is one of the power point software in a computer that combines text, images and video into a single unit using links, allowing students to be more interested in viewing learning video shows.

There have been numerous studies on the development of audio visual media for learning, for istance, social sciences (Muliani, 2018; Gonçalves, 2017), geography (Gayatri, et.al. (2017), reading
(Shabiralyani et.al., 2015), higher educational level (Rasul, 2011). However, how the audio visual media have been utilized in natural science learning at the elementary school learning. That was covered by this research.

Development of instructional media through hyperlink-based audio visuals which is a medium for using computers so that students can be attracted to learn and not feel bored anymore, because the instructional media is in the form of video shows.

The development of instructional media through hyperlink-based audio visuals was carried out as one to overcome the problem of students' boredom in learning, especially the sixth grade students of SDN Basanah Tanahmerah Bangkalan.

\section{LITERATURE REVIEW}

A. Instructional Media According to Gerlach \& Elly (Arsyad, 2016) suggest that media is human, material, or event that construct students' condition to be able to acquire knowledge, skills, or attitudes. AECT (Association of Education and Communication Technology, 1977) gives limitations on media as all forms and channels used to convey messages or information.

Each type of media has specific capabilities and characteristics or features that can be used for specific purposes as well. Ega (2016) describes the types of instructional media, among others: Visual Media, Audio Visual, Computers, Microsoft Power Point, Internet, Multimedia.

The use of instructional media can arouse students' interest and enthusiasm to participate in the learning process.

\section{B. Audio Visual}

According to Ega (2016) Audio Visual is a media that displays images and sounds simultaneously while communicating information. The combination of two elements that make 
audio visual media have better capabilities. Audio visual is a media that consists of auditive media (listening) and visual (viewing). Video media is the same as audio-visual media, although the physical form is different, audio-visual media has similarities with films, which both display moving images. Hyperlinks are defined as media presentations that can facilitate connecting a different file or connecting multiple slides to a PowerPoint file so that it appears quickly, which makes it easy without looking for the file or slide to be seen manually.

\section{Science}

Science is a study that was originally obtained and developed through experiments (inductive) and then developed based on theory (deductive). There are two things that are related and cannot be separated from the Sciences, namely science as a product, in the form of factual, conceptual, procedural, and metacognitive knowledge, and also science as a process, namely: scientific work. Now the wider science includes: concepts, science, processes, values and scientific attitudes, science applications in daily life, and the creativity (Wisudawati \& Sulistyowati, 2017).

There are three terms involved in science lessons, namely: science, knowledge and nature. Knowledge is everything that humans know. Natural knowledge is the knowledge of the universe and contents. Science is scientific knowledge (sensibly). Science is defined as the study of causes due to the events in nature (Wisudawati and Sulistyowati, 2017)

\section{RESEARCH METHOD}

The method used in this research was research and development. This method is used to create a product and test the effectiveness of the product so that it can be used in the world of education.

This research was designed using Dick and Carey's (1996) learning development model. In this development model there were 10 stages, but the researchers only took 9 stages because this research was carried out only in the trial of learning media products.

The development procedure basically consists of two main objectives. They are: the development of media products and the effectiveness of the product in achieving its objectives.

The steps of product development used included:

1. Preparing the materials to be studied in the learning activities;

2. Making a power point file;

3. Power points were modified using hyperlinks so that they were interesting;

4. Material writing was integrated with voice related to material;

5. Displaying images on slides;

6. Displaying videos.

In the development stage of instructional media through hyperlink-based audio visuals, there are several stages that will be used in this research, namely:

1. The stages used in the initial analysis phase are:

a. Curriculum Study

This study was conducted to determine the material that would be presented in learning activities, explore the subject matter of the theme, so that the development of instructional media could determine some minimal basic competencies that had to be mastered by students, and another goal is to make the students not bored to learn.

b. Study on motivation learning

The study was conducted to determine the motivation of students in learning activities by using the study of learning motivation theory.

c. Study of the media through hyperlinkbased audio visuals

The study was used as an effort to develop the media through hyperlinkbased audio visuals, where the use of IT was modified with sound and images combined to make the students more interested in learning, without being 
burdened to remember the material that was not liked by students. Therefore, the students were motivated to remember after using learning media through hyperlink-based audio visuals.

2. Development of Hyperlink-Based Audio Visual Media Design Phase, the activities carried out at this stage are:

a. Determination of basic competencies that must be achieved by the students This activity was carried out as a guide in formulating the learning objectives through the development of instructional media, so that the material delivered in the learning activities related to the expected goals.

b. Determination of Time allocation

The determination of this time allocation was to provide a time limit in conveying each topic of material. Determination of time allocation was to consider effective learning activities.

c. Development of learning content

The content of learning was tailored to the basic competencies that had to be achieved by the students, through the material to be delivered, later the students would easily accept and understand the material delivered through the learning media.

d. Development of hyperlink-based audio visual media content.

The development of instructional media through the audio visuals was adapted to the material conditions of the students to be delivered, so learning was fun through the broadcast media that had been modified with the video shows.

The Model Test/Product test is presented as follows:

\section{Test Design}

The trial was conducted to determine the level of attractiveness, validity and effectiveness of instructional media products. The instructional media products through hyperlink-based audio visuals. Level of validity and the attractiveness of the instructional media is known from the results of the analysis of the trial activities through several stages, namely the consultation stage, the expert validation stage and the field trial stage.

\section{Test Subject}

The subjects were tested in developing measuring instruments, among others.

a. Material experts

The material experts act as the development of instructional media is a Master or a higher degree in education and. have competence in the field of education.

b. Media experts

Media experts that act in media development are experts in the field of design and instructional media.

c. Students

The try outs were carried out on the sixth grade students of SDN Basanah Tanahmerah, Bangkalan.

2. Types of Data and Instrumentation

Data is defined as information that can be used as a basis for the study. The data used were qualitative and quantitative data

a. Qualitative data are data derived from criticism, suggestions and comments from the experts about the development of instructional media.

b. Quantitative data is data in the form of assessment points given by experts and students to the development of instructional media through hyperlinkbased audio visual.

The instrument used in data collection is in the form of a questionnaire that is used as the subject of assessment, the purpose of the questionnaire is to obtain qualitative and quantitative data for the ideal and feasibility of the product resulting from the development of instructional media.

\section{Data Analysis}


The data analysis techniques used in the study were describing all opinions, suggestions and responses of the validator from critics and suggestions. The data from the questionnaire was qualitative data that were quantified by using a Likert scale with four-level criteria, then analyzed through a percentage score of the item score on each answer according to the question set. To determine the percentage, the researcher used the following formula:

$$
p=\frac{\sum x}{\sum y} x 100 \%
$$

$\mathrm{P}$ is percentage of proper test

$\sum \mathrm{x}=$ total score of validator answers (real score)

$\sum \mathrm{y}=$ total highest score (expected score)

\section{RESULTS AND DISCUSSION}

This study used the trial phase carried out by the media experts, material experts and a total of 20 students, the following is the data presented for the trial.

This research and development was based on the needs of the teachers and students, aiming to improve the quality of education in learning by creating the instructional media through IT that was effective, efficient and had attraction for students. Through the help of the instructional media created for the learning activities, it could facilitate students in accepting learning, the students could also learn on their own at home, the media was made in the form of Power Points that were equipped with animated sounds and videos along with interesting images.

The design of a hyperlink-based audio visual media display was in the form of power point in science subjects about the solar system with images, sounds, videos, animations, slides that were modified so the sixth-grade students were interested.

The retrieval of test results on the hyperlink-based audio visual learning media was conducted by the material experts, media experts and teachers. The retrieval of data from the results that were presented to the students after the instructional media got a proper assessment from the media experts and material experts.

The trial was given to 20 sixth grade students of SDN Basanah Tanahmerah. The results of the trials that were conducted to the material experts, media experts and students can be seen as follows. The expert material validation data was obtained from the results of filling out the questionnaire by the material expert.

The expert material validation was given to lecturers in their fields. The instrument given to the material contained 10 questions. Some comments and suggestions obtained from the material expert validation were references that were used as a basis for revision before the trial was carried out to the students.

The results of the calculation of the percentage were obtained $80 \%$ of the results of the material expert validation got a good value qualification and no need to be revised.

The results of the calculation of the percentage obtained by $83 \%$ of the results of the validation of the instructional media expert got a good value qualification and no need to be revised.

The validation of classroom teachers was conducted by filling up the questionnaire. It was the same as questionnaires given to the material experts.

The results of the calculation of the percentage obtained by $84 \%$ of the results of the material expert validation got a good value qualification and no need to be revised.

All of these results of the trial data from the validation of the material experts and media experts were used as a basis for revising this media product. The trial conducted by the material experts with the percentage of the material experts, based on indicators that were about the solar system as the center of the solar system is the sun, and the celestial objects that 
surround the sun. The material appropriateness with indicators obtained the percentage of the trial results of the $80 \%$ with valid and proper classifications to be used as media in learning.

The trials conducted by the media experts who were lecturers who were capable in their fields, obtained a percentage of $83 \%$ with a proper classification. Feasibility is a form of product results that were declared valid by the media experts and could then be used as a media in the process of the learning activities.

Before conducting the revision validation, the researchers first made consultations with the material experts with the aim of obtaining material that was suitable for the needs of the teachers and students. There were still many shortcomings that the researchers needed to improve to get the results of the material that was made as expected by the material expert. Based on the results of the analysis of the media products written by the researcher and needed to be revised to improve the results of the development of the instructional media and the results after being tested by the media experts and the results were proper to be used as media in the process of learning activities.

\section{CONCLUSION}

To conclude, from the design expert responses, all media development that had been made were in accordance with what the students expected, so the students were more interested in understanding and learning material from the results of the development of learning media through hyperlink-based audio visual.

The teacher guidance component also made the teachers interested in being able to use IT by developing instructional media through hyperlink-based audio visuals, because the results obtained that students were interested in the learning.

From the material expert responses, it is in accordance with the contents of the material given to the students that can be seen from the drawing and explanation of the material and everything was clear.

After revising the results of the development of instructional media through hyperlink-based audio visuals, it is suggested that the teacher needs to develop more interesting and innovative media so that students will be more interested in learning.Next, the results of development are taken into consideration by the principal as the top supervisor so that the teacher will be more creative in learning. School as an arcade so that it can help teachers to develop more in developing instructional media for use in the learning process.It is necessary to revise it in the following year so that the media created can be further increased to more creative media.

\section{REFERENCES}

Al-Khayyat, A.S.J. (2016). The Impact of Audio-Visual Aids (AVA) and Computerize Materials (CM) on University ESP Students' Progress in English Language. International Journal of Education and Research. 4 (1), 273-283.

Arsyad, A. (2016), Media Pembelajaran, Edisi Revisi. Jakarta: PT RajagrafindoPersada

Asnawir \& Umar, M. B. (2002). Media Pembelajaran. Jakarta: Ciputat Press

Dick, W., \& Carey, L. (1996). The systematic design of instruction. 4th ed. New York, NY: Harper Collin.

Daryanto. (2012), Media Pembelajaran, Bandung: PT. Sarana Tutorial Nurani Sejahtera.

Degeng, N. S. (2013). Ilmu Pembelajaran Klasifikasi Variabel untuk Pengembangan Teori dan Penelitian, Aras Media.

Gayatri, T., Soegijanto, H., \& Rintayati, P. (2017). Development of 
Contextual Teaching LearningBased Audio Visual Adobe Flash Media to Improve Critical Thinking Ability of Geography Learning at Senior High School. IOP Conference Series: Earth and Environmental Science. 145 012004., 1-10.doi $: 10.1088 / 1755-$ 1315/145/1/012004.

Gonçalves, A.D.S., de Araújo, V.L., Pereira, S., \& Moreira, I.X. (2017). Utilizing Audiovisual Media and Learning Motivation on Student Achievement of Social Department Grade VIII Student Fatumeta, Dili. International Research-Based Education Journal, 1 (1), 5-15.

Hamza B, U. (2012). Model Pembelajaran Menciptakan Proses Belajar Mengajar yang Kreatif dan Efektif,. Jakarta: PT. Bumi Aksara.

Muliani, E. (2018). Audiovisual Helping Teacher and Students in Teaching Learning Process of Social Sciences Subject at SDN 024868 Binjai. VISION: Journal of Language, Literature \& Education, 14 (14), 1-11.

Nasrip \& Fatirul, N. (2015), Pengembangan Media PembelajaranBerbasis

Multimedia Interaktifdengan Macromedia Flash Mata Diklat Mengoperasikan Paket Program Pengolah Angka pada Program Keahlian Akutansi untuk Siswa sekolah Menengah KejuruanKelas X, Volume 5 nomor 1http://docplayer.info/5958895 4-Smk-kota-belitar-2universitas-pgri-adi-buanasurabaya.html
Rachmania, Y. I. (2009). as quoted in Pengembangan Bahan Ajar dengan Pendekatan Realistik Pokok Bahasan Segiempat Untuk Siswa SMP Kelas VII. Program Sarjanan UM.

Rasul, S., Bukhs, Q., \& Batool, S. (2011). A study to analyze the effectiveness of audio visual aids in teaching learning process at university level. Procedia - Social and Behavioral Sciences, 28 (2011) $78 \quad-\quad 81$. doi:10.1016/j.sbspro.2011.11.

Sadiman, A. S. et. al. (2014). Media Pendidikan: Pengertian, Pengembangan dan Pemanfaatannya, Jakarta: Rajawali Pers.

Shabiralyani, G., Hasan, K.S., Hamad, N., \& Iqbal, N. (2015). Impact of Visual Aids in Enhancing the Learning Process Case Research: District Dera Ghazi Khan. Journal of Education and Practice, 9 (16), 226-235.

Sugiyono. (2010), Metode Penelitian Kuantitatif, Kualitatif dan $R \& D$. Bandung. CV Alfabeta.

Suharsimi, A. (2003). Dasar-dasar Evaluasi Pendidikan, Jakarta: Bumi Aksara

Microsoft
Yogyakarta, CV. Andi Offset.
Wati, E. R, (2016). Ragam Media
Pembelajaran. Kata Pena

Wisudawati, A. W. \& Sulistyowati, 2017. Metodologi Pembelajaran IPA, Jakarta. Bumi Aksara Woolfolk, A. (2004). Educational Psychology (9th ed.). Boston: Allyn and Bacon. 